\title{
Designing Robotics-based Science Lessons Aligned with the Three Dimen- sions of NGSS-plus-5E Model: A Content Analysis (Fundamental)
}

\section{Dr. Hye Sun You, NYU Tandon School of Engineering}

Hye Sun You received a Ph.D. from a STEM education program at the University of Texas at Austin. She earned her master's degree in science education and bachelor's degree in chemistry from Yonsei University in South Korea. Prior to entering academia, she spent several years teaching middle school science. Her research interests center upon interdisciplinary learning and teaching, and technology-integrated teaching practices in STEM education. In her dissertation work, she developed and validated a new interdisciplinary assessment in the context of carbon cycling for high school and college students using Item Response Theory. She is also interested in developing robotics-embedded curricula and teaching practices in a reform-oriented approach. Currently, a primary focus of her work at New York University is to guide the development of new lessons and instructional practices for a professional development program under a DR K-12 research project funded by NSF.

\section{Sonia Mary Chacko, NYU Tandon School of Engineering}

Sonia Mary Chacko received her B.Tech. degree in Electronics and Communication Engineering from Mahatma Gandhi University, Kottayam, India, and M.Tech degree in Mechatronics Engineering from NITK, Surathkal, India. She is currently a Ph.D. student in Mechanical Engineering at NYU Tandon School of Engineering, Brooklyn, NY. She is serving as a research assistant under an NSF-funded DR $\mathrm{K}-12$ project.

\section{Dr. Sheila Borges Rajguru, NYU Tandon School of Engineering}

Dr. Sheila Borges Rajguru is the Assistant Director of the Center for K-12 STEM Education, NYU Tandon School of Engineering. As the Center's STEAM educator and researcher she works with engineers and faculty to provide professional development to K-12 STEM teachers with a focus on social justice. She is currently Co-Principal Investigator on two NSF-grants that provide robotics/mechatronics PD to science, math, and technology teachers. In addition, she is the projects director of the ARISE program. This full-time, seven-week program includes: college level workshops and seminars, and a high level research experience in NYU faculty labs. Her commitment to diversity and equity is paramount to her work in STEAM and activism. As a former Adjunct Professor at Teachers College, Columbia University and biomedical scientist in immunology Dr. Borges balances the world of what scientists do and brings that to STEAM education in order to provide culturally relevant professional development and curricula that aligns to the Next Generation Science Standards (NGSS). Her free time is spent hiking, growing spiritually, and enjoying her family and friends. Moreover, Dr. Borges is treasurer and co-chair of the Northeastern Association for Science Teacher Education (NE-ASTE) where faculty, researchers, and educators inform STEM teaching and learning and inform policy.

\section{Dr. Vikram Kapila, NYU Tandon School of Engineering}

Vikram Kapila is a Professor of Mechanical Engineering at NYU Tandon School of Engineering (NYU Tandon), where he directs a Mechatronics, Controls, and Robotics Laboratory, a Research Experience for Teachers Site in Mechatronics and Entrepreneurship, a DR K-12 research project, and an ITEST research project, all funded by NSF. He has held visiting positions with the Air Force Research Laboratories in Dayton, OH. His research interests include K-12 STEM education, mechatronics, robotics, and control system technology. Under a Research Experience for Teachers Site, a DR K-12 project, and GK-12 Fellows programs, funded by NSF, and the Central Brooklyn STEM Initiative (CBSI), funded by six philanthropic foundations, he has conducted significant K-12 education, training, mentoring, and outreach activities to integrate engineering concepts in science classrooms and labs of dozens of New York City public schools. He received NYU Tandon's 2002, 2008, 2011, and 2014 Jacobs Excellence in Education Award, 2002 Jacobs Innovation Grant, 2003 Distinguished Teacher Award, and 2012 Inaugural Distinguished Award for Excellence in the category Inspiration through Leadership. Moreover, he is a recipient 
of 2014-2015 University Distinguished Teaching Award at NYU. His scholarly activities have included 3 edited books, 9 chapters in edited books, 1 book review, 62 journal articles, and 154 conference papers. He has mentored 1 B.S., 35 M.S., and 5 Ph.D. thesis students; 58 undergraduate research students and 11 undergraduate senior design project teams; over $500 \mathrm{~K}-12$ teachers and 118 high school student researchers; and 18 undergraduate GK-12 Fellows and 59 graduate GK-12 Fellows. Moreover, he directs K-12 education, training, mentoring, and outreach programs that enrich the STEM education of over 1,000 students annually. 


\section{Designing Robotics-based Science Lessons Aligned with the Three Dimensions of NGSS-plus-5E Model: A Content Analysis (Fundamental)}

\section{Introduction}

Lesson planning is a cognitive process which entails deliberative thinking about issues concerning the objective of student performance, extent of planned activities, logical organization of content, types of instructional processes to be deployed, and strategies for assessing students at the end of the lesson [1,2]. Among a myriad of factors requiring consideration in contemplating to plan and prepare for an instructional activity, teachers' understanding of national standards, especially, their objectives and important themes, can serve as effective drivers for lesson planning and instructional practices. For example, the Next Generation Science Standards (NGSS) [3] purposefully and explicitly promote teachers to adopt and weave the three NGSS dimensions of science and engineering practices (SEPs), disciplinary core ideas (DCIs), and crosscutting concepts (CCCs) as an authentic mean for students to develop their abilities to experience and explain scientific phenomena. Moreover, the NGSS encourages incorporating engineering practices that help students develop and strengthen their abilities to apply their knowledge for defining problems and designing solutions. The NGSS has already been adopted by 19 states and an additional 16 states have revised their state science standards in ways that mirror the NGSS. Since the implementation of these standards, recent research has argued that familiarity and experiences with concrete illustrations of standards-aligned lessons [4] and immersion in standards-aligned professional development (PD) [5] can prepare science teachers to comprehend and articulate the objectives of the NGSS as well as reflect the nature of specific content elements and practices to build standard-aligned lessons.

In addition to the national standards, an instructional model serves as an essential ingredient in the development of specific lesson plans and curricular materials [6]. As an example, the 5E model is a well-known instructional model that is grounded in both a conceptual change model of learning and constructivism approach to learning [7]. Many teachers, science education faculty, and state departments of education have adopted the $5 \mathrm{E}$ model as a useful guide for inquiry-based pedagogy.

Prior research has indicated that there is a lack of understanding of the 5E model components and its practices [8,9]. Moreover, lack of familiarity with the current standards and difficulty in meeting the expectations set by them hamper one's ability to make lessons more meaningful vis-à-vis the current reform [10]. PD is known to play a critical role in providing teachers with knowledge and skills to familiarize themselves with educational shifts inherent in the current reform and aid them in successfully implementing new curricula and changing teaching practices [11]. The purpose of this study is to understand to what extent teachers participating in PD build robotics-integrated and 
NGSS-aligned science lessons. The study focuses on addressing the following two specific questions related to lesson planning.

1) To what extent are the lesson plans developed by science and math teachers aligned with the three-dimensional learning of the NGSS and the 5E model?

2) How can the lessons be improved for three-dimensional learning?

In the process of designing lessons, four overarching tenets were used as a guide. The first tenet mandates that the lesson content is aligned with performance expectation for DCIs shown in the NGSS. The second tenet concerns the classroom teaching of a lesson with SEPs, specifically, using robotics technology. The third tenet is that teachers incorporate the use of CCCs. The fourth tenet follows the 5E model to build teachers' lessons that facilitate inquiry-based instruction.

\section{Theoretical Framework and Literature Review}

In tracing the history of lesson planning concepts, we encountered many theories and models that have suggested myriad courses of action to prepare effective lesson plans. Following an extensive review of research literature for planning lessons, we identified two theoretical models that are relevant to our work with a focus on technology integrated teaching: the Substitution Augmentation Modification Redefinition (SAMR) Model developed by Puentedura [12] and the 5E Model developed by Bybee and his colleagues [6]. Below we briefly characterize key elements of these two theoretical models and illustrate the 5E model and the steps for NGSS-aligned lesson planning based on $[3,13]$.

\subsection{Substitution Augmentation Modification Redefinition (SAMR) Model}

The SAMR model [12] formulates a structured approach for examining technology infusion into the teaching and learning process. The SAMR model suggests that there are four different degrees (or levels) of classroom technology integration that fall along a continuum of progression. A technology integration that is farther along on the continuum renders a more effective instructional enhancement with a potential for transforming learning. The model supports teachers to design and develop lesson plans that utilize technology in which authentic student engagement and achievement level are the learning outcomes. Figure 1 shows the assigned four levels of technology integration that subsume and go beyond the three categories of technology functions in pedagogy (viz., replacement, amplification, and transformation) suggested in [14]. At the substitution level, technology is used to perform the same task as was done before the introduction of technology. Technology simply acts as a direct tool substitute with no functional change (i.e., a simple replacement). At the augmentation level, technology acts as a direct tool substitute with functional improvement (i.e., to amplify). The level of modification indicates that technology helps induce 
significant task redesign. Finally, at the redefinition level, technology allows for the creation of new tasks that would have been previously inconceivable.

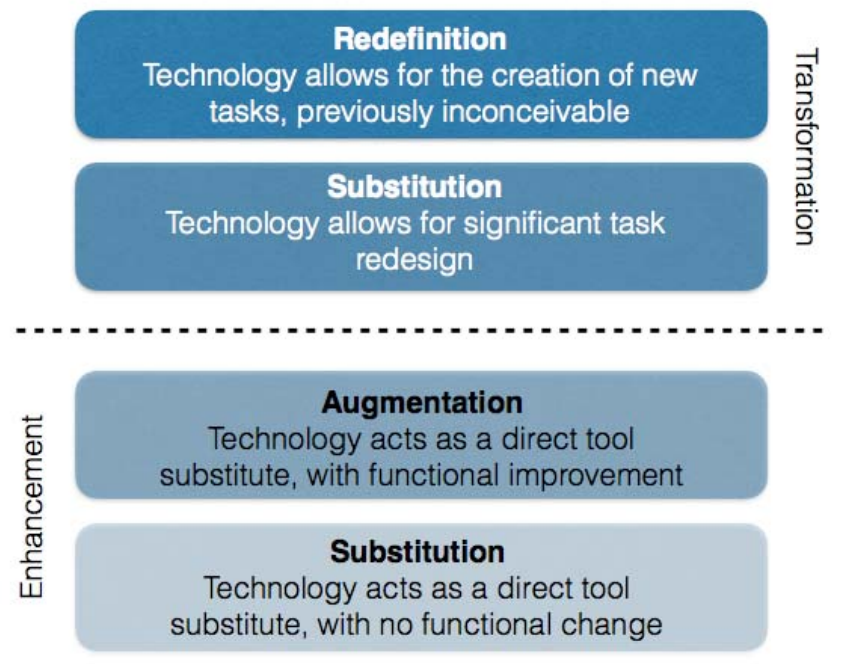

Figure 1: The SAMR model of [15].

\subsubsection{E Instructional Model}

Bybee et al. [6] proposed the 5E instructional model design to assist teachers in developing inquiry-based lesson plans. The model consists of five phases, each beginning with the letter "E": Engagement, Exploration, Explanation, Elaboration, and Evaluation. The 5E model is a modification of the Learning Cycle used as a model for planning lessons since its introduction in the 1960s [16]. The learning cycle of [16] has three phases that include Exploration, Concept Introduction, and Concept Application. To these three phases of the learning cycle, Bybee and his colleagues added two additional phases, namely, the engagement and evaluation. According to [17], the three phases of the learning cycle, Exploration, Concept Introduction, and Concept Application align, respectively, with the Engage and Explore, Explain, and Elaborate and Evaluate phases of the $5 \mathrm{E}$ model.

In the 5E model, an instruction is initiated with the engagement phase wherein teachers aim to engage students in a task through which they can gauge students' prior knowledge and help students make connections between prior knowledge and present learning experiences. Through a series of questions, teachers can engender interest among students and initiate their learning. In the second phase, i.e., exploration, teachers encourage students to engage in creative thinking for examining scientific questions, testing hypotheses, predicting the outcome of a situation, and trying alternative approaches to solve a problem. Following the exploration phase comes the explanation phase. For this phase to succeed, teachers need to introduce students to a hands-on activity in which they are able to construct and explain science concepts based on their experience. 
In the elaboration phase, which aligns with the concept application phase of the learning cycle, teachers provide an opportunity for students to draw upon prior information to make connections and apply their newly acquired knowledge and evidence to different situations. In the final evaluation phase, teachers assess students' understanding of the concepts and skills and judge their progress using various assessment tools. Overall, the 5E instructional model has been used as a guide for framing lessons and designing inquiry-based learning to impart students with an opportunity to construct their own understanding of scientific concepts.

\subsection{NGSS and Lesson Planning}

The Framework for K-12 Science Education [18] puts forth a new vision to promote actively engaging students in SEPs while affording them opportunities for applying CCCs to deepen their understanding of DCIs. A collaboration involving 26 lead states has translated this threedimensional (3D) vision for learning and teaching into the NGSS. According to the NGSS [3] and the Framework [18], DCIs are a small set of the fundamental, overarching ideas that are necessary for understanding and explaining scientific phenomena. Moreover, the eight SEPs identified in NGSS [3] reflect the major activities that scientists and engineers use to investigate the natural world and design the engineered world. Finally, the seven CCCs of NGSS [3] can be used to offer alternative perspectives and make connections across disparate disciplines or situations for making sense of phenomena or solving problems.

The NGSS is structured as performance expectations (PEs) that integrate the three dimensions together and that require students to build a conceptual foundation for explaining phenomena, solving problems, and making decisions. The standards indicate that PEs specify what students are expected to know and how a student would be assessed at the end of instruction [13,19]. For example, PE MS-PS3-4 from middle school level is [3] "Plan an investigation to determine the relationships among the energy transferred, the type of matter, the mass, and the change in the average kinetic energy of the particles as measured by the temperature of the sample." In this PE, a student must employ the SEPs of Planning and Carrying out Investigations. To do this, teachers must use the DCIs related to Conservation of Energy and Energy Transfer. Additionally, the CCCs of Scale, Proportion, and Quantity, and Energy and Matter provide a focus for the task. Table 1 illustrates a graphic representation of how PE MS-PS3-4 is constructed from the three dimensions.

The standards can be used as a reference to help teachers formulate and create a general approach for lesson planning. For example, Krajcik et al. [13] have examined how to design a sequence of lessons to meet the intent of the NGSS and they have suggested a 10-step process (see Table 2) that teachers can use. Moreover, as an alternative to the 10-step process of Krajcik et al. [13], the NSTA [20] has proposed a relatively shorter version of the steps to create lessons that build on the NGSS (see Table 3). Even though the steps in Tables 2 and 3 are listed in a linear fashion, in practice, the entire process can be iterated upon as one engages in the lesson development. 
Table 1: Blending the three dimensions to form performance expectations (MS-PS3-4) in the NGSS [3].

\begin{tabular}{|c|c|c|c|}
\hline \multicolumn{4}{|c|}{ MS-PS3 Energy } \\
\hline MS-PS3-4. & \multicolumn{3}{|c|}{$\begin{array}{l}\text { Plan an investigation to determine the relationships among the energy transferred, the type of matter, the mass, and the change in the average kinetic energy of } \\
\text { the particles as measured by the temperature of the sample. [Clarification Statement: Examples of experiments could include comparing final water temperatures after } \\
\text { different masses of ice melted in the same volume of water with the same initial temperature, the temperature change of samples of different materials with the same mass as } \\
\text { they cool or heat in the environment, or the same material with different masses when a specific amount of energy is added.] [Assessment Boundary: Assessment does not } \\
\text { include calculating the total amount of thermal energy transferred.] }\end{array}$} \\
\hline \multicolumn{4}{|c|}{ The performance expectations above were developed using the following elements from the NRC document A Framework for K-12 Science Education: } \\
\hline \multicolumn{2}{|c|}{ Science and Engineering Practices } & Disciplinary Core Ideas & Crosscutting Concepts \\
\hline \multicolumn{2}{|c|}{$\begin{array}{l}\text { Planning and Carrying Out Investigations } \\
\text { Planning and carrying out investigations to answer questions } \\
\text { or test solutions to problems in } 6-8 \text { builds on K-5 } \\
\text { experiences and progresses to include investigations that } \\
\text { use multiple variables and provide evidence to support } \\
\text { explanations or design solutions. } \\
\text { - Plan an investigation individually and collaboratively, and } \\
\text { in the design: identify independent and dependent } \\
\text { variables and controls, what tools are needed to do the } \\
\text { gathering, how measurements will be recorded, and how } \\
\text { many data are needed to support a claim. (MS-PS3-4) }\end{array}$} & $\begin{array}{l}\text { PS3.B: Conservation of Energy and Energy Transfer } \\
\text { The amount of energy transfer needed to change the } \\
\text { temperature of a matter sample by a given amount } \\
\text { depends on the nature of the matter, the size of the } \\
\text { sample, and the environment. (MS-PS3-4) }\end{array}$ & $\begin{array}{l}\text { Scale, Proportion, and Quantity } \\
\text { Proportional relationships (e.g. speed as the ratio of } \\
\text { distance traveled to time taken) among different types of } \\
\text { quantities provide information about the magnitude of } \\
\text { properties and processes. (MS-PS3-1),(MS-PS3-4) }\end{array}$ \\
\hline \multicolumn{4}{|c|}{$\begin{array}{l}\text { Connections to other DCls in this grade-band. MS.PS1.A (MS-PS3-4); MS.PS2.A (MS-PS3-1),(MS-PS3-4),(MS-PS3-5); MS.ESS2.C (MS-PS3-3),(MS-PS3-4); MS.ESS2.D (MS-PS3-3),(MS- } \\
\text { PS3-4); MS.ESS3.D (MS-PS3-4) }\end{array}$} \\
\hline \multicolumn{4}{|c|}{$\begin{array}{l}\text { Articulation across grade-bands: 4.PS3.C (MS-PS3-4),(MS-PS3-5); HS.PS1.B (MS-PS3-4); HS.PS3.A (MS-PS3-1),(MS-PS3- 4),(MS-PS3-5); HS.PS3.B (MS-PS3-1),(MS-PS3-2),(MS-PS3- } \\
\text { 3),(MS-PS3-4).(MS-PS3-5) }\end{array}$} \\
\hline \multicolumn{4}{|c|}{$\begin{array}{l}\text { Common Core State Standards Connections: } \\
\text { ELA } 2 \text { iteracy - } \\
\text { RST.6-8.3 Follow precisely a multistep procedure when carrying out experiments, taking measurements, or performing technical tasks. (MS-PS3-3),(MS-PS3-4) }\end{array}$} \\
\hline \multicolumn{4}{|c|}{$\begin{array}{l}\text { Mathematics - } \\
\text { 6.SP.B.5 Summarize numerical data sets in relation to their context. (MS-PS3-4) }\end{array}$} \\
\hline
\end{tabular}

\subsection{Engineering Design Process (EDP)}

As indicated in the Introduction, the SEPs of the NGSS [3] include the engineering practices of defining problems and designing solutions. Modeling, experimentation, computational thinking, professional communication, etc., represent additional engineering practices in the SEPs of the NGSS [3]. Moreover, inclusion of engineering as one of the four science domains (viz., Life Science; Earth and Space Science; Physical Science; and Engineering, Technology, and the Application of Science) ensures that the DCIs of the NGSS sufficiently address the engineering design process (EDP). Consideration of the EDP in K-12 STEM education by the education and research community [21,22] predates its inclusion in the NGSS. For example, [21] suggested an eight-step EDP consisting of (i) identifying and (ii) researching a problem, (iii) developing and (iv) selecting solutions, (v) prototyping, (vi) testing/evaluation and (vii) communicating solutions, and (viii) redesigning. Alternatively, to engage and expose young children to engineering, [22] developed a five-step EDP that includes: (i) asking, (ii) imagining, (iii) planning, (iv) creating, and (v) improving. The engineering-related DCIs of NGSS [3] incorporate defining problems, developing solutions, and optimizing solutions as essential ingredients of the EDP. 
Table 2: A 10-step sequence for planning NGSS-aligned lessons [13].

\begin{tabular}{|c|c|}
\hline No. & Description \\
\hline 1. & $\begin{array}{l}\text { Select PEs-The NGSS includes a bundle of PEs (several related PEs) from a single topic or DCI. The ideas } \\
\text { encapsulated in the PE bundle must be developed progressively across multiple lessons over time. To search } \\
\text { for related PEs, use the following NGSS website. https://www.nextgenscience.org/standards/standards }\end{array}$ \\
\hline 2. & $\begin{array}{l}\text { Inspect the PEs-Review each selected PE, the corresponding clarification statements, and its assessment } \\
\text { boundaries to establish the scope of instruction. }\end{array}$ \\
\hline 3. & $\begin{array}{l}\text { Examine DCIs, SEPs, and CCCs associated with the selected PEs-Understanding the three dimensions is } \\
\text { paramount for developing instruction that develops students' capacity to construct their understanding of } \\
\text { science and apply it to problem-solving. }\end{array}$ \\
\hline 4. & $\begin{array}{l}\text { Closely examine the DCIs and PEs-It is essential to identify the content ideas that students need to know } \\
\text { and establish the mechanisms by which they can demonstrate their understanding of DCIs and their mastery } \\
\text { of PEs. }\end{array}$ \\
\hline 5. & $\begin{array}{l}\text { Identify additional SEPs-Identify practices that augment the pedagogy of specified DCIs and CCCs. } \\
\text { Consideration of appropriate supplementary practices, beyond the ones specified for a standard, can aid in } \\
\text { the development of a coherent sequence of learning tasks that integrate various SEPs with the related DCIs } \\
\text { and CCCs. For selecting the practices, refer to Appendix F, Science and Engineering Practices in NGSS. } \\
\text { https://www.nap.edu/read/18290/chapter/12 }\end{array}$ \\
\hline 6. & $\begin{array}{l}\text { Develop lesson level PEs-Lesson level expectations need to be developed to scaffold the development of } \\
\text { understanding expressed in the bundle of the PEs. The lesson level performances encapsulate a finer grain } \\
\text { understanding of the PEs. }\end{array}$ \\
\hline 7. & $\begin{array}{l}\text { Determine the acceptable evidence for assessing lesson level PEs-Establish the criteria for acceptable } \\
\text { evidence that students demonstrate lesson level PEs. Having specified the evidence, it is necessary to develop } \\
\text { both formative and summative assessments for eliciting students' evolving understanding. }\end{array}$ \\
\hline 8. & $\begin{array}{l}\text { Select related Common Core State Standards for Mathematics (CCSS-M) and Common Core State Standards } \\
\text { for Literacy (CCSS-L) - The NGSS includes CCSS-M and CCSS-L aligned with various PEs as evidenced } \\
\text { in the connection boxes. }\end{array}$ \\
\hline 9. & $\begin{array}{l}\text { Carefully construct a storyline - The constructed storyline can begin from students' prior ideas and evolve } \\
\text { into sophisticated ideas of how student understanding, especially, the DCIs, SEPs, and CCCs, may develop } \\
\text { over time. }\end{array}$ \\
\hline 10. & $\begin{array}{l}\text { Ask the following question, "How do the lesson(s) help students move towards an understanding of the } \\
\text { PEs?" - After completing the lesson development process, it is important to review the developed lesson } \\
\text { plan and reconfirm that it can build students' knowledge and comprehension of the PEs. Here, it is vital to } \\
\text { unpack the development of lesson level PEs and the results of the tasks and lessons. }\end{array}$ \\
\hline
\end{tabular}


Table 3: A four-step sequence for planning NGSS-aligned lessons [20].

\begin{tabular}{|c|l|}
\hline No. & \multicolumn{1}{c|}{ Description } \\
\hline 1. & $\begin{array}{l}\text { Identify a PE-Teachers identify a particular PE from the standards and a series of activities that bridge that } \\
\text { PE with students' prior knowledge. }\end{array}$ \\
\hline 2. & $\begin{array}{l}\text { Select the three dimensions-Teacher review the DCIs corresponding to a given PE and brainstorm some } \\
\text { phenomena to explain the targeted core ideas. Once some useful phenomena are identified, they carefully } \\
\text { consider the eight SEPs to identify ones that can aid in the investigation of such phenomena. Similarly, they } \\
\text { consider the seven CCCs to identify ones that are central to examining the phenomena. For each lesson, they } \\
\text { select the SEPs that are key to the lesson. }\end{array}$ \\
\hline 3. & $\begin{array}{l}\text { Write a learning performance-Teachers write a single statement of a learning performance describing the } \\
\text { objective of the lesson while considering the three dimensions together. A learning performance statement } \\
\text { has a similar format and structure as a PE. However, unlike a performance expectation, a learning } \\
\text { performance focuses only on a portion of a PE, usually a single step in the instructional sequence. }\end{array}$ \\
\hline 4. & $\begin{array}{l}\text { Ask the right questions-When writing learning performance statements, the following questions } \\
\text { recommended by the NSTA may be helpful for consideration. What prior knowledge is needed to understand } \\
\text { the DCIs and what are the corresponding misconceptions? How could a lesson be designed to address } \\
\text { misconceptions and draw upon prior knowledge? At what level of thinking should students be able to } \\
\text { understand and apply the new concept? What alternative knowledge representations or technology can } \\
\text { support learning to make sense of phenomena encapsulated in DCIs? What SEPs can be employed by } \\
\text { students as they explain phenomena or perform experiential learning activities to learn this DCI? Are there } \\
\text { any CCCs that can support the learning and understanding of DCIs and SEPs? What connections to the } \\
\text { Common Core State Standards (CCSS) could be emphasized in the instructional sequence? }\end{array}$ \\
\hline
\end{tabular}

\section{Methods}

\subsection{Context and Participants}

This study was conducted within the context of a PD project centered on robotics-integrated science and math education. Our research team invited only the middle school teachers who had participated in a prior summer PD (2016 or 2017) to participate. In the prior PD, teachers experienced and practiced effective approaches for integrating robotics-based science and math lessons in their classrooms. For a more successful integration of robotics into classrooms, the research team updated the PD workshop by adapting from extensive research documented in existing literature regarding the best practices for $\mathrm{PD}$, learning theories, the engineering design process, and use of robotics in STEM education. The PD of the current study was conducted during the course of three weeks in the summer of 2018 at the NYU Tandon School of Engineering. The developers created a weekly structure of engagement for participants. PD resources (e.g., PowerPoint slides, lesson templates, sample lessons, reading materials, robot programs, etc.) for each week were posted to a cloud storage drive for sharing with the PD participants. The first week of the PD focused on introducing the NGSS, including its 3D model, the 5E instructional model, and several sample lessons developed by the facilitators. From week two onwards, the participants concentrated on the process of designing, testing, and reviewing new lessons. At the end of the workshop, the participants had the opportunity to share several lessons tailored to their own school and grade level. A weekly agenda for the PD program is outlined in Table 4. 
Table 4: PD program timeline and activity summary.

\begin{tabular}{|c|c|}
\hline Timeline & Activity summary \\
\hline Week 1 & $\begin{array}{l}\text { - Introduce the outline of the PD, the NGSS, and the 5E model. } \\
\text { - Present four sample NGSS plus 5E lessons developed by facilitators on each day. PD } \\
\text { participants and facilitators review and discuss each lesson. The facilitators integrate } \\
\text { feedback to update these lessons. } \\
\text { - Introduce LEGO EV3 programming challenges to brush up the participants programming } \\
\text { skills. }\end{array}$ \\
\hline Week 2 & $\begin{array}{l}\text { Divide participants into two teams (Team1: two science and one math teachers; Team 2: two } \\
\text { math and one science teachers) and engage them to work on their first lesson in the following } \\
\text { sequence. } \\
\text { - Select a topic from the middle school curriculum that is aligned with the NGSS. } \\
\text { - Build a lesson plan using the NGSS plus } 5 \text { E template. } \\
\text { - Design activities using LEGO robots (classroom activity sheets, EV3 programs, etc.). } \\
\text { - Present the lesson plan, demonstrate the LEGO activity, and gather feedback from peers. } \\
\text { - Review and integrate feedback from peer teachers and facilitators. } \\
\text { - Revise the newly developed lessons. } \\
\text { Design another lesson plan in groups with the sequence of activities being same as in Week } 2 \text {. }\end{array}$ \\
\hline
\end{tabular}

The PD participants, six middle school teachers (three science and three math) in grades 6-8, were exposed to a variety of science and math topics that are aligned with the NGSS and which offered opportunities for robotics integration into their traditional classrooms. Working in two teams of three teachers each, they were encouraged and supported to develop at least two lesson plans per team. A discussion forum allowed the participants to ask questions, seek answers, and provide feedback on lesson plans. During the PD, the participants delivered to peer teachers and facilitators lessons that use robotics within the three dimensional model of the NGSS scaffolded with the 5E instructional model. Moreover, they actively sought and received feedback on their lesson plans from the peer teachers and PD facilitators through presentations. Table 5 summarizes background information of the teacher participants.

During the academic year, the participating teachers started bringing robotics to their classrooms and implementing the curricula that they designed during the PD. They have received on-going support from the PD facilitators throughout the implementation of their lesson plans.

Table 5: Background information of teacher participants.

\begin{tabular}{|ccccccc|}
\hline Pseudonym & Kate & Lisa & Emily & Natalie & Brandon & Kristen \\
\hline Gender & $\mathrm{F}$ & $\mathrm{F}$ & $\mathrm{F}$ & $\mathrm{F}$ & $\mathrm{M}$ & $\mathrm{F}$ \\
\hline Race/Ethnicity & White & Hispanic & Asian & African American & Asian & Asian \\
\hline Level of education & $\begin{array}{c}\text { MS in } \\
\text { Education }\end{array}$ & M.B.A & M.A.T & MS in Biology & $\begin{array}{c}\text { MS in } \\
\text { Education }\end{array}$ & M.A.T \\
\hline $\begin{array}{c}\text { Years of teaching } \\
\text { experience }\end{array}$ & 17 & 20 & 1 & 23 & 28 & 12 \\
\hline $\begin{array}{c}\text { Grade level and } \\
\text { subjects currently } \\
\text { teaching }\end{array}$ & $7^{\text {th }}$ Biology & $8^{\text {th }}$ Math & $6^{\text {th }}$ Science & $8^{\text {th }}$ Math & $8^{\text {th }}$ Math & $8^{\text {th }}$ Science \\
\hline
\end{tabular}




\subsection{Data Sources and Analysis}

The method for the analysis is qualitative content analysis of the lesson plans created by two groups of middle school science and math teachers. Content analysis is appropriate to make a valid inference by examining themes and key phrases from document sources.

During the PD, the two teams of three middle school teachers each collaboratively developed lesson plans which focused on ways to implement the 5E inquiry-based and the NGSS-aligned science instruction. We were interested in exploring, examining, and describing how the lesson plans are connected to the NGSS and the 5E model and gaining an in-depth understanding of the inquiry and exploratory process of the artifacts of the teachers.

We focused on two exemplary lesson units, viz., antibiotic resistance and genetic mutations, which were analyzed using two vetted rubrics: the Evaluating the Quality of Instructional Products (EQUIP) rubric for Science v3 developed by Achieve and the National Science Teachers Association [23] and the 5E Inquiry Lesson Plan (ILP) rubric v2 developed by Goldston et al. [17]. The EQuIP rubric allows identification of alignment of lessons to the 3D learning model of the NGSS and rates the overall quality of lessons. The rubric has three evaluation categories: I. Alignment to the NGSS, II. Instructional Supports, and III. Monitoring Student Progress [23], however in this study we focus only on category I (see Appendix A) to assess elements of 3D learning - a primary innovation of the NGSS. The EQuIP rubric uses $0-3$ scale denoting "Inadequate (or no) evidence to meet any of the criteria in the category" (0); "Adequate evidence to meet at least one criterion in the category" (1); "Adequate evidence to meet all three criteria in the category" (2); and "Extensive evidence to meet at least two criteria" (3). The 5E ILPv2 rubric was developed for use in evaluating teachers' inquiry-based $5 \mathrm{E}$ lesson plans. The rubric contains a total of 21 items: three items for elaborate phase; four items for each phase of engage, explore, and evaluation; and six items for the explain phase. Each item is a Likert-type scale that ranges from 0-Unacceptable to 4-Excellent with a total of 84 points (see Appendix B).

In this study, analyzing lesson plans using the rubrics provided opportunities for suggestions and feedback for improvement to developers and it informs the development of new lessons by the project team. All data were triangulated by the PD facilitators with the same perspectives to establish validity and reliability.

\section{Results}

\subsection{Alignment of the First Lesson with the Three-dimensional Learning of NGSS and 5E Model}

The first lesson, antibiotic resistance, was designed and intended for $8^{\text {th }}$ grade students. The lesson plan begins with a brief description of the PEs and specific learning outcomes. In this lesson, 
students are expected to construct their understanding of how natural selection leads to the predominance of certain traits in a population and the suppression of others, and to consider the impact an antibiotic has on a bacterial population over many generations. This topic is aligned with the PEs, MS-LS4-4, and MS-LS4-6. In the engage phase, a teacher will access students' prior knowledge regarding the importance of antibiotics in our life, why we need to be alert about developing resistance to antibiotics, and the strategies that we can utilize to obviate this problem. The teacher will provide the lesson's anchor phenomenon through driving questions and try to elicit student response after showing a video about antibiotic resistant superbugs. In both the explain and elaborate phases, students will be exposed to hands-on experiences that will allow them to test how bacteria of four different types grow in a petri dish, and to describe the change of frequency of bacterial traits. In one activity, students will predict the frequency of different traits of bacteria and compare the probabilities based on their prediction and actual measured frequencies. Another activity will allow students to analyze and interpret data regarding an antibiotic's efficacy (unspecified SEP in the lesson-analyzing and interpreting data). In this activity, as leaders of a developing pharmaceutical company, students will determine whether the antibiotics are effective or not and they will find effective ways of marketing the antibiotics. According to the designers, a series of activities and the introduction part of the lesson will stimulate students' interest and will support their sense-making of a phenomenon about bacteria growth with antibiotic resistance and designing solutions to combat antibiotic resistance.

The lesson provides opportunities to use multiple grade appropriate elements of each of the three dimensions from the NGSS. For example, in the bacteria growth activity using robotics technology LEGO EV3, students can use the "Bacterial Growth Gyro" program running on a robot to simulate data about the percentage of one of four bacteria in the petri dish. Specifically, the robot is placed at the center of a circle and repeats the process of turning by a certain angle and stopping according to a set of programmed parameters. This activity appears similar to a robot drawing a pie chart (see Figure 2). As the robot turns from one of its stopped positions to the next stopped position, the corresponding turn angle represents the percentage of petri dish covered by one of the bacteria for days 2-4. Having collected the data using the robot, students can calculate the actual frequency of a trait in the bacterial population by using the proportion for each bacterial trait. In this activity, a student can create mathematical representations to utilize the proportions to demonstrate how the size of the population increases (SEP-using mathematics), and thus, they will learn that while bacteria with certain traits have increased in numbers, others have decreased (DCI-MS-LS4.B). This activity taps into the understanding of a cause and effect (CCC) relationship - the presence or absence of certain traits can lead to better survival rates. In the explanation phase, students will compare the probabilities based on their prediction to the actual measured frequencies (SEP-using mathematics) and construct an explanation for why the actual frequency either matches or does not match students' prediction (DCI-MS-LS4.B; SEP-constructing explanations). As evidence, students will create graphs to describe the change in those frequencies and support their explanation about certain traits for better survival rates (CCC-cause and effect). 
This lesson provides opportunities for students to develop their scientific literacy with a coherent three-dimensional approach. Through constructing an explanation of a quantitative relationship between the increase in number of new traits in bacteria and higher chance of developing resistance to antibiotics (SEP-constructing explanations) and causal relationships on how the improper use of antibiotics leads to bacteria's resistance (CCC-cause and effect), students will consider the development of antibiotic resistance through natural selection and will develop a list of criteria and constraints for solutions to mitigate antibiotic resistance (DCI-MS-LS4.C).
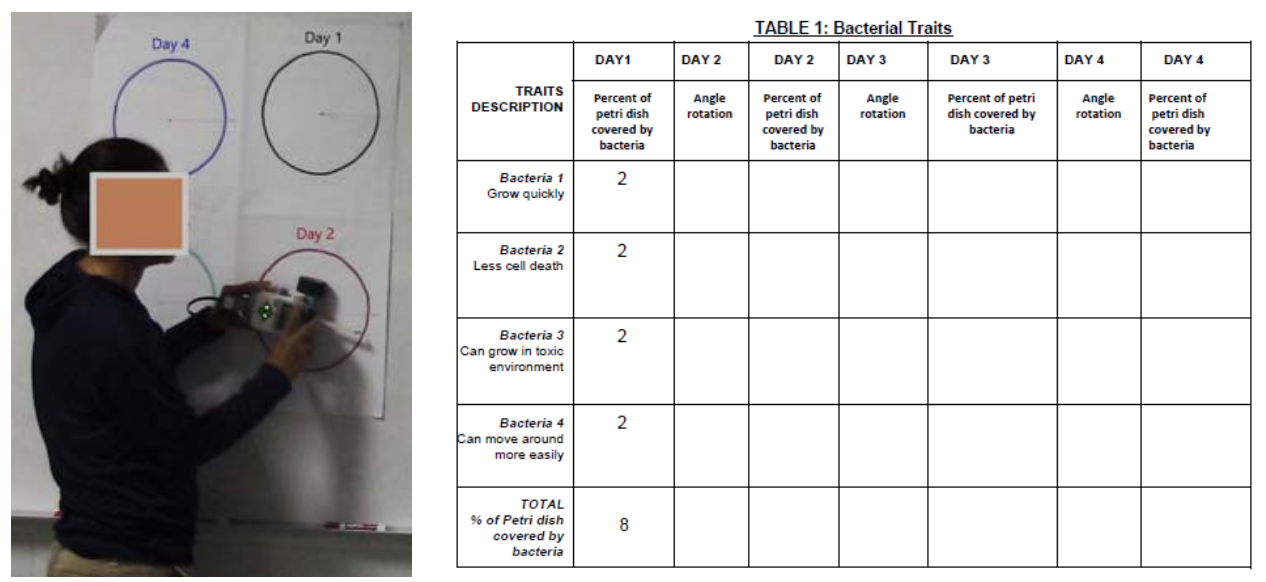

Figure 2: Robot activity for antibiotic resistance during the PD.

\subsection{Suggestions to Improve the First Lesson for Three-dimensional Learning}

By considering the following suggestions, the lesson can be improved. Even though teachers mention the SEPs and the CCCs based on the NGSS, supplementary practices and CCCs should be incorporated to augment the instructional practices. For example, when observing the pattern of a bacterial population over time to recognize the role of natural selection, "pattern" is a possible $\mathrm{CCC}$ that can be included in the lesson plan. Moreover, since this lesson engages students in collecting data and using graphs from the activities, students have the opportunity to participate in the practice of "analyzing and interpreting data", applying their new knowledge to solve a practical problem. The use of LEGO robot and 5E instruction model for performing lesson activities affords opportunities to embed the EDP models of NGSS [3] and of [21,22]. For example, to learn and experience the engineering practice of defining problems, students may be tasked with defining and understanding the robotics-based STEM learning activity. Similarly, the designing solutions practice can be addressed through research, development, and experimentation activities wherein students contribute individually and collaboratively. In seeking and identifying the best solution to the problem, students may be engaged in brainstorming, testing, evaluation, and iterative refinement. Finally, they ought to communicate results to their teacher and peers through presentations. Table 6 shows a snapshot of the antibiotic resistance lesson including the threedimensions of the NGSS and their implementation through the 5E elements. 
Table 6: Summary of the antibiotic resistance lesson.

\begin{tabular}{|c|c|}
\hline \multicolumn{2}{|l|}{$\begin{array}{l}\text { Standard } \\
\text { MS-LS4 B }\end{array}$} \\
\hline \multicolumn{2}{|c|}{ Performance Expectation } \\
\hline \multicolumn{2}{|c|}{$\begin{array}{l}\text { MS-LS4-4. Construct an explanation based on evidence that describes how genetic variations of traits in a } \\
\text { population increase some individuals' probability of surviving and reproducing in a specific environment. } \\
\text { MS-LS4-6. Use mathematical representations to support explanations of how natural selection may lead to } \\
\text { increases and decreases of specific traits in populations over time. }\end{array}$} \\
\hline 3 Dimensions & $\begin{array}{ll}5 \mathrm{E} \text { Connections } \\
\end{array}$ \\
\hline \multicolumn{2}{|l|}{ Science and Engineering Practices } \\
\hline Constructing Explanations & $\begin{array}{l}\text { - Explaining students' conclusions about natural } \\
\text { selection based on the collected data regarding } \\
\text { bacterial growth. }\end{array}$ \\
\hline Using Mathematics & $\begin{array}{l}\text { - Exploring how bacteria populations with } \\
\text { different traits have changed by calculating } \\
\text { frequencies. }\end{array}$ \\
\hline \multicolumn{2}{|l|}{ Disciplinary Core Ideas } \\
\hline $\begin{array}{l}\text { LS4.B: Natural Selection } \\
\text { Natural selection leads to the predominance of certain } \\
\text { traits in a population, and the suppression of others. }\end{array}$ & $\begin{array}{l}\text { - Observing (exploring) that while bacteria with } \\
\text { certain traits have increased in numbers, the } \\
\text { others have decreased. }\end{array}$ \\
\hline $\begin{array}{l}\text { LS4.C: Adaptation } \\
\text { Adaptation by natural selection acting over generations is } \\
\text { one important process by which species change over time } \\
\text { in response to changes in environmental conditions. Traits } \\
\text { that support successful survival and reproduction in the } \\
\text { new environment become more common; those that do not } \\
\text { become less common. Thus, the distribution of traits in } \\
\text { population changes. }\end{array}$ & $\begin{array}{l}\text { - Elaborating the natural selection concept through } \\
\text { the phenomenon of acquisition of antibiotic } \\
\text { resistance trait. }\end{array}$ \\
\hline \multicolumn{2}{|l|}{ Crosscutting Concepts } \\
\hline Cause and Effect & $\begin{array}{l}\text { - Engaging in discussion to form an understanding } \\
\text { that frequent or improper use of antibiotics can } \\
\text { cause bacteria to become resistant to them. } \\
\text { - Elaborating the understanding that the presence } \\
\text { or absence of certain traits leads to better survival } \\
\text { rates for bacteria. } \\
\text { - Evaluating students' rationale about why } \\
\text { antibiotics overuse increases bacterial resistance. }\end{array}$ \\
\hline
\end{tabular}

\subsection{Alignment of the Second Lesson with the Three-dimensional Learning of NGSS and 5E Model}

The second lesson, genetic mutations, was also designed for $8^{\text {th }}$ grade students. It was developed based on PE MS-LS3-1 regarding effects of gene mutations on the structure and function of an organism. Here students are expected to develop, use, and describe their understanding about why structural change to genes may affect proteins, thus resulting in harmful, beneficial, or neutral effects on the structure and function of the organism. In the engage phase, teachers will tap into students' prior knowledge by providing an interesting activity on the topic. For example, a teacher can give students two sets of images of a karyotype (i.e., the number and appearance of 
chromosomes) and ask them about the differences between the pairs. In the activity, students will have the opportunity to consider changes in genetic material and start developing initial explanations (unspecified SEP in the lesson-asking questions). Furthermore, through several examples of genetic diseases (e.g., cystic fibrosis, sickle cell anemia), students will learn that there are many mutations within the DNA that cannot be seen on a karyotype. For example, cystic fibrosis is caused by a mutation in one nucleotide in the DNA. The teacher will ask students to explain, through the voice of an actual patient, how cystic fibrosis affects the human body. This engage section serves an important purpose in making sense of the phenomena and motivating problem-solving.

In the explore phase, students will be actively engaged with materials to develop new understandings. The teacher will provide medical history cards of six patients to students including their genetic test results. Each student group will seek to determine which patient has which genetic disorder. To determine mutations present in the genetic code, students will be given a LEGO EV3 robot with six programs corresponding to the conditions of six patients. They will collect data by utilizing the robot and running its programs. As a simulation, the robot will be placed on a paper and start to move along chromosomes lined up in a row. When the robot stops at a specific location, it will indicate an error by sounding an alarm and display a number. The displayed number will indicate the number of the chromosome with a mutation. Students will observe the robot's activity and figure out each patient's specific chromosomes with mutations. It is possible that the program simulating a specific patient exhibits more than one mutated chromosome. Figure 3 shows the mutations on chromosome \# 5 and \#10 for patient 4.

This activity leads to practices such as (i) "planning and carrying out investigations" through experimentation and testing the hypothesis with a robot and (ii) "analyzing and interpreting data" by using a robot to record data and determine whether the data supports the hypothesis. However, the activities of this robotics-based lesson lack practices such as creating and employing a model to characterize scientific concepts or engineering processes or engaging in discourse about an existing model. The aforementioned SEPs are pertinent to engineers as they design, analyze, and build systems. In the explain phase, the teacher will guide the investigation and ask several prompting questions to help students' understanding that not all genetic mutations cause diseases, and not all disorders have a genetic basis (DCI-MS-LS3-1). For enrichment, teachers can introduce to students that mutations also affect cell division process that could result in cancer (CCCstructure and function). Students will create a circle graph using data from the Center for Disease Control on the recent rates of deaths caused by cancer and analyzing it (SEP-analyzing and interpreting data). Students will have an opportunity to share their pie charts and discuss several questions (e.g., which type of cancer affects both men and women?). Suggested questions for evaluation will encourage students to use evidence to support a claim or to apply knowledge for explaining how or why something occurred, which facilitates the integration of the three dimensions. 


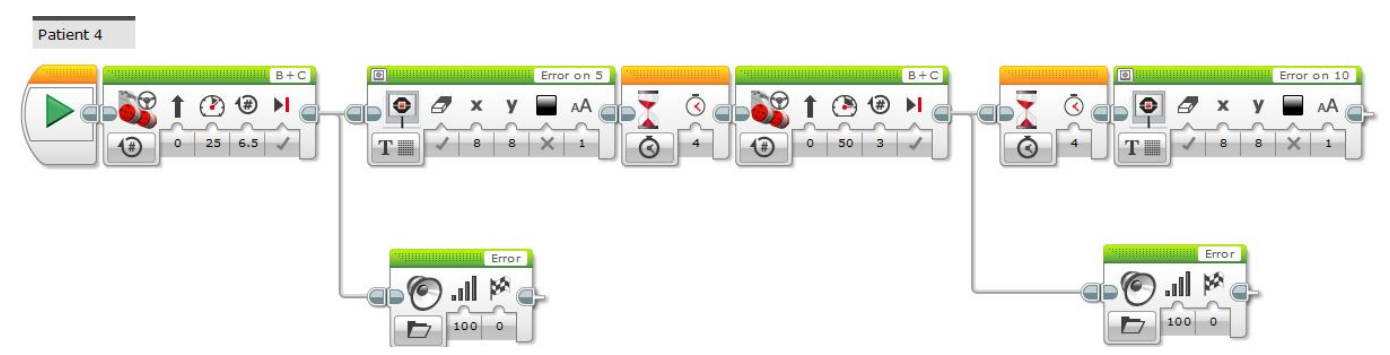

Figure 3: EV3 Program of patient 4 (mutations in chromosome 5 and 10).

\subsection{Suggestions to Improve the Second Lesson for Three-dimensional Learning}

This lesson plan is of high quality regarding teachers' use of the phenomena - the effects of mutations on the organism level - to anchor instruction through the activities. However, not all activities build a culminating explanation. For example, the data analysis of rates of deaths caused by cancer does not enable students to develop an understanding of structure and function. Almost all the questions appearing at the end of the activity prompt students to simply interpret information from the data like comparing the numbers. None of the questions provides an opportunity for students to reflect on how this learning relates to the initial phenomenon mentioned in the introduction section. This finding indicates that teachers are not always explicit about the phenomenon related to the core ideas when developing activities.

This lesson shows "developing models" is a key practice for students to use throughout the learning sequence yet it does not demonstrate the activity where students construct models in explaining phenomena using diagrams, computer simulations, mathematical formulations, and/or analogies. Moreover, this mutation lesson does not reflect all possible SEPs that students can be engaged to perform. In the introduction section, asking questions ought to be included as a fundamental practice because a teacher is asking questions that require a description of how the phenomena work and how those can be empirically tested. Moreover, from the activities, students collect the data and interpret them to answer the questions. This practice aligns with "analyzing and interpreting data". As indicated earlier, lessons in robotics activities ought to be framed to engage students in the engineering practices and the EDP. These examples demonstrate that teachers are not always explicit about the practices that grounded their planned instruction. In recognizing and selecting the practices, teachers may need to understand that other practices can be involved in instructional sequence besides the SEPs addressed in the NGSS.

The lesson plan indicates that "structure and function" is a CCC that helps students to engage in science practices and to develop core ideas. A clarifying note from the lesson states: "The CCC of this standard is also addressed in this section [by] using the example of sickle cell anemia to demonstrate mutations in DNA sequence affect the structure and function of red blood cells." This note may create a misconception about the CCC of "structure and function". Since the NGSS 
focuses on the causal relationship of structure and function, it should be emphasized in the following way, "the structure of red blood cells is modified due to DNA point mutation, which in turn leads to change in their properties and functions." The lesson plan approaches the NGSS alignment somewhat but the lesson data shows that the teachers struggled to effectively interweave three dimensions and develop a coherent storyline grounded in the phenomena. Table 7 shows a snapshot of the genetic mutation lesson plan including the three-dimensions of the NGSS and their implementation through the $5 \mathrm{E}$ elements.

Table 7: Summary of the genetic mutation lesson.

\begin{tabular}{|c|c|}
\hline \multicolumn{2}{|c|}{ Standard } \\
\hline \multicolumn{2}{|c|}{$\begin{array}{l}\text { MS-LS3 Heredity: Inheritance and Variation of Traits } \\
\text { https://www.nextgenscience.org/sites/default/files/NGSS DCI Combined 11.6.13.pdf (p. 65) }\end{array}$} \\
\hline \multicolumn{2}{|c|}{ Performance Expectation } \\
\hline \multicolumn{2}{|c|}{$\begin{array}{l}\text { MS-LS3-1. Develop and use a model to describe why structural changes to genes (mutations) located on } \\
\text { chromosomes may affect proteins and may result in harmful, beneficial, or neutral effects to the structure and } \\
\text { function of the organism. }\end{array}$} \\
\hline 3 Dimensions & 5E Connections \\
\hline \multicolumn{2}{|l|}{ Science and Engineering Practices } \\
\hline Developing and Using Models & $\begin{array}{l}\text { - Exploring an activity to predict possible genetic } \\
\text { diseases using a model based on patient medical } \\
\text { history and mutation data collected by the EV3 } \\
\text { robot. } \\
\text { - Elaborating the development of a model-a circle } \\
\text { graph-to represent the number of cancers and } \\
\text { deaths. }\end{array}$ \\
\hline \multicolumn{2}{|l|}{ Disciplinary Core Ideas } \\
\hline $\begin{array}{l}\text { LS3.A: Inheritance of Traits } \\
\text { Genes are located in the chromosomes of cells, with each } \\
\text { chromosome pair containing two variants of each of many } \\
\text { distinct genes. Each distinct gene chiefly controls the } \\
\text { production of specific proteins, which in turn affects the } \\
\text { traits of the individual. Changes (mutations) to genes can } \\
\text { result in changes to proteins, which can affect the structures } \\
\text { and functions of the organism and thereby change traits. }\end{array}$ & $\begin{array}{l}\text { - Engaging students' prior knowledge that genes } \\
\text { - Exe located on chromosomes. } \\
\text { - Explaining that changes or mutations may or may } \\
\text { - Evaluating the understanding about the } \\
\text { connection that changes in the structure of DNA } \\
\text { sequence (mutation) may result in (1)the change } \\
\text { in function. }\end{array}$ \\
\hline \multicolumn{2}{|l|}{ Crosscutting Concepts } \\
\hline Structure and Function & $\begin{array}{l}\text { - Engaging students through an example of sickle } \\
\text { cell anemia to demonstrate that mutations on } \\
\text { DNA sequence affect the structure and function } \\
\text { of red blood cells. } \\
\text { - Evaluating the scientific fact that the mutations } \\
\text { on DNA result in (1) the change in the organism's } \\
\text { function, which may lead to a harmful disorder or } \\
\text { may be beneficial or no effect on the organism. }\end{array}$ \\
\hline
\end{tabular}

\subsection{Lesson Assessments using the NGSS and 5E Rubrics}

Our research team transformed the qualitative analysis of lesson plan to quantitative measurement by using both the EQuIP rubric and 5E ILPv2 rubric. The results indicate that on the $0-3$ scale of 
the EQuIP rubric, overall, antibiotic resistance lesson was scored as "2" showing adequate evidence to meet the NGSS alignment, and genetic mutations lesson was rated as " 1 ", indicating SEP elements require further enhancement. According to the rubric description, if the lesson does not score at least a " 2 ", further revision should be carried out.

Next, the 5E ILPv2 rubric developed by Goldston et al. [17] was utilized to evaluate the extent to which each lesson incorporates the 5E's. On the $0-4$ scale of the rubric, the analysis of the "antibiotic resistance" lesson plan reveals the following scores for: the engage (14/16), explore $(15 / 16)$, explain $(18 / 24)$, elaborate $(9 / 12)$, and evaluate $(6 / 16)$ phases. This lesson lacks a clear indication of how the teacher explains the concept or illustrates skills with different approaches (e.g., direct instruction, group discussion, or the use of technology, etc.). During the explain phase, the teacher is not directed to assess students' present understanding during the activity and there is a lack of a logical transition from the explain phase to the elaborate phase. In the evaluate stage, the lesson showed one broad question for formative assessment. Based on the lesson's objective, the teachers may need to develop more items for a student to communicate and justify her/his explanations. Moreover, it is suggested that a summative evaluation should be created to match the lesson objectives including a rubric with appropriate criteria. The analysis of the "genetic mutations" lesson plan revealed the following scores for the engage (13/16), explore $(12 / 16)$, explain (19/24), elaborate (9/12), and evaluate (6/16) phases. This lesson is not sufficiently developed to ascertain students' prior knowledge in the engage phase and it does not provide a variety of approaches to explain concepts during the explain phase. The lesson does not include appropriate and measurable criteria (i.e., rubric) for formative assessment or the methods of summative evaluation. Overall, the two lesson plan scores were about "good" vis-à-vis the use of $5 \mathrm{E}$ strategies in lesson planning, indicating that another teacher could use these lesson plans (or phases) by modifying them based on the aforementioned feedback. The details of the evaluation of both lessons are provided below in Tables 8 and 9.

\section{Discussion}

A teacher's lesson plans can provide a unique view of how s/he organizes teaching to provide learning experiences to students. Teachers must be cognizant of the various considerations necessary to successfully plan lessons [2]. One of the most influential components for the planning is the standards. Teachers use the standards as references that guide instruction. However, many teachers face new challenges to learn the objective and vision of the current reform [24]. 
Table 8: Summary of the antibiotic lesson using EQuIP and 5E rubrics.

\begin{tabular}{|c|c|c|c|}
\hline $\begin{array}{c}\text { Lesson criteria: NGSS 3D } \\
\text { design }\end{array}$ & $\begin{array}{l}\text { Specific evidence from materials and reviewer's } \\
\text { reasoning }\end{array}$ & \multicolumn{2}{|c|}{ Quality } \\
\hline $\begin{array}{l}\text { A. Explaining } \\
\text { Phenomena/Designing } \\
\text { Solutions }\end{array}$ & $\begin{array}{l}\text { Engage in a discussion on the problem of antibiotics in } \\
\text { our life } \\
\text { - Explore making sense of a phenomenon about bacteria } \\
\text { growth with different traits } \\
\text { - Explain the quantitative relationship about bacteria } \\
\text { growth }\end{array}$ & \multicolumn{2}{|c|}{ Adequate } \\
\hline B. Three Dimensions (3D) & & Quality & \multirow{4}{*}{ Adequate } \\
\hline a. SEPs & $\begin{array}{l}\text { - Constructing an explanation } \\
\text { - Using mathematical representations }\end{array}$ & Extensive & \\
\hline b. DCIs & $\begin{array}{l}\text { - Natural Selection (MS-LS4.B) } \\
\text { - Adaptation (MS-LS4.C) } \\
\end{array}$ & Extensive & \\
\hline c. $\mathrm{CCCs}$ & - Cause and Effect & Adequate & \\
\hline C. Integrating $3 \mathrm{D}$ & 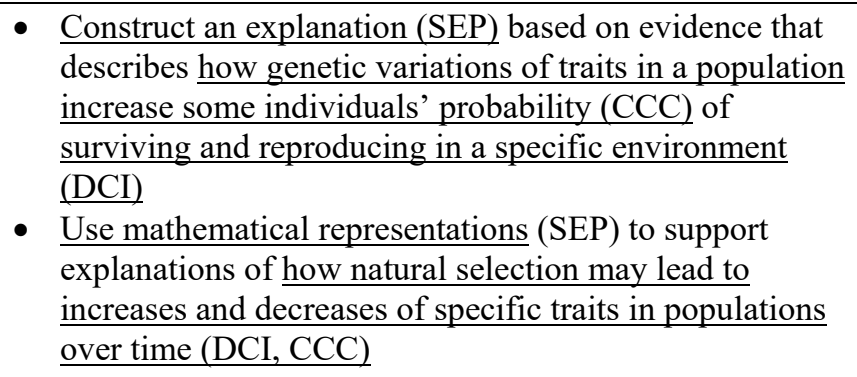 & \multicolumn{2}{|c|}{ Extensive } \\
\hline $\begin{array}{l}\text { Overall rating for criteria } \\
\text { A to } \mathrm{C}\end{array}$ & \multicolumn{3}{|l|}{$\begin{array}{llll}0 & 1 & \underline{\mathbf{2}} & 3 \\
\end{array}$} \\
\hline \multicolumn{4}{|c|}{ 5E Review of the Antibiotics Lesson } \\
\hline \multirow{2}{*}{\multicolumn{3}{|c|}{$\begin{array}{l}\text { Exploration-Phase } 1 \text { (Engage and Explore) } \\
\text { Engage (elicits students' prior knowledge, raises interest/motivation, opens discussion, and leads into } \\
\text { the exploration) }\end{array}$}} & Score \\
\hline & & & $14 / 16$ \\
\hline \multicolumn{3}{|c|}{$\begin{array}{l}\text { Explore (presents instructions, involves hands-on and inquiry-based activities, shows evidence of } \\
\text { learning) }\end{array}$} & $15 / 16$ \\
\hline \multicolumn{3}{|c|}{ Invention-Phase 2 (Explain) } & \\
\hline \multicolumn{3}{|c|}{$\begin{array}{l}\text { Explain (logical transition from the explore phase, includes teacher questions that lead to the } \\
\text { development of concepts and skills, includes interactive discussion, contains a complete explanation } \\
\text { of the concepts, provides a variety of approaches to explain the concepts, and allows the teacher to } \\
\text { assess student understanding) }\end{array}$} & $18 / 24$ \\
\hline \multicolumn{3}{|c|}{ Expansion-Phase 3 (Elaborate and Evaluate) } & \\
\hline \multicolumn{3}{|c|}{$\begin{array}{l}\text { Elaborate (logical transition from the explain phase, applies new concepts and skills, and finds real- } \\
\text { life connections) }\end{array}$} & $9 / 12$ \\
\hline \multicolumn{3}{|c|}{$\begin{array}{l}\text { Evaluation (includes summative evaluation with a variety of forms/approaches, matches the } \\
\text { objectives, and includes clear and measurable criteria) }\end{array}$} & $6 / 16$ \\
\hline \multicolumn{3}{|c|}{ Overall rating } & $012 \underline{\mathbf{3}} 4$ \\
\hline
\end{tabular}


Table 9: Review summary of the genetic mutation lesson using EQuIP and 5E rubrics.

\begin{tabular}{|c|c|c|c|}
\hline $\begin{array}{l}\text { Lesson criteria: NGSS } \\
\text { 3D design }\end{array}$ & $\begin{array}{l}\text { Specific evidence from materials and reviewer's } \\
\text { reasoning }\end{array}$ & \multicolumn{2}{|c|}{ Quality } \\
\hline $\begin{array}{l}\text { A. Explaining } \\
\text { Phenomena/Designing } \\
\text { Solutions }\end{array}$ & $\begin{array}{l}\text { - Engage in an activity using karyotype images with } \\
\text { mutations } \\
\text { - Explore analysis of possible genetic diagnosis on } \\
\text { background text and data } \\
\text { - Explain changes in mutations which may or may not } \\
\text { result in a disorder }\end{array}$ & \multicolumn{2}{|c|}{ Adequate } \\
\hline B. Three Dimensions (3D) & & Quality & \multirow{4}{*}{$\begin{array}{l}\text { Inadequate } \\
\text { (All } 3 \\
\text { dimensions } \\
\text { must be rated } \\
\text { at least } \\
\text { "adequate" to } \\
\text { mark } \\
\text { "adequate" } \\
\text { overall) }\end{array}$} \\
\hline a. SEPs & - Developing and using models & Inadequate & \\
\hline b. DCIs & - Inheritance of Traits (MS-LS3.A) & Adequate & \\
\hline c. $\mathrm{CCCs}$ & - Structure and Function & Adequate & \\
\hline C. Integrating $3 \mathrm{D}$ & $\begin{array}{l}\text { - Develop and use a model (SEP) to describe genes' } \\
\text { mutations located on chromosomes (DCI) and } \\
\text { understand that the mutations to genes may or may not } \\
\text { result in disease (DCI, CCC) }\end{array}$ & \multicolumn{2}{|c|}{ Adequate } \\
\hline $\begin{array}{l}\text { Overall rating for criteria } \\
\text { A to C }\end{array}$ & \multicolumn{3}{|l|}{$\begin{array}{llll}0 & 1 & 2 & 3 \\
\end{array}$} \\
\hline \multicolumn{4}{|c|}{$5 \mathrm{E}$ review of antibiotics lesson } \\
\hline \multirow{2}{*}{\multicolumn{3}{|c|}{$\begin{array}{l}\text { Exploration—Phase } 1 \text { (Engage and Explore) } \\
\text { Engage (elicits students' prior knowledge, raises interest/motivation, opens discussion, and leads } \\
\text { into the exploration) }\end{array}$}} & Score \\
\hline & & & $13 / 16$ \\
\hline \multicolumn{3}{|c|}{$\begin{array}{l}\text { Explore (presents instructions, involves hands-on and inquiry-based activities, shows evidence of } \\
\text { learning) }\end{array}$} & $12 / 16$ \\
\hline \multicolumn{3}{|c|}{ Invention-Phase 2 (Explain) } & \\
\hline \multicolumn{3}{|c|}{$\begin{array}{l}\text { Explain (logical transition from the explore phase, includes teacher questions that lead to the } \\
\text { development of concepts and skills, includes interactive discussion, contains a complete explanation } \\
\text { of the concepts, provides a variety of approaches to explain the concepts, and allows the teacher to } \\
\text { assess student understanding) }\end{array}$} & $19 / 24$ \\
\hline \multicolumn{3}{|c|}{ Expansion-Phase 3 (Elaborate and Evaluate) } & \\
\hline \multicolumn{3}{|c|}{$\begin{array}{l}\text { Elaborate (logical transition from the explain phase, applies new concepts and skills, and finds real- } \\
\text { life connections) }\end{array}$} & $9 / 12$ \\
\hline \multicolumn{3}{|c|}{$\begin{array}{l}\text { Evaluation (includes summative evaluation with a variety of forms/approaches, matches the } \\
\text { objectives, and includes clear and measurable criteria) }\end{array}$} & $6 / 16$ \\
\hline \multicolumn{3}{|c|}{ Overall rating } & $012 \underline{\mathbf{3}} 4$ \\
\hline
\end{tabular}


This study was designed to examine how knowledge and skills gained during the PD translate into teachers' ability to plan NGSS-aligned lesson within the 5E model with the use of robotics technology. One limitation of the current study is the nature of the data-while some quantitative data was collected in this study, it is primarily an in-depth, qualitative content analysis of a small number of lesson plans, and no general conclusions can be drawn without the collection and analysis of additional data. In a future study, lesson plan content analyses will be interpreted alongside interview and classroom observation data to gain a more complete picture of the threedimensional teaching process.

Our lesson plan design was influenced by the previous work of [13], however, a major difference of our approach is the incorporation of the $5 \mathrm{E}$ model in the second step of Table 2 as a guiding principle of the lesson sequence. Our PD employed the following seven-step lesson design process and guided the teachers through it. (i) We recommend starting with PEs to think about what a student ought to know at the end of a particular topic. Once teachers identify PEs and a grade level, (ii) they review and learn the NGSS architecture and 5E instructional model. Having understood those aspects, (iii) they examine the DCIs corresponding to the PEs under consideration. Pursuant to the selection of DCIs, teachers brainstorm about relevant phenomena and then think about the various ways (e.g., hands-on activities) with which students can examine and explore the phenomena. Our hands-on activities focused on the use of LEGO EV3 robot and programming, which supports engaging students in SEPs and the EDP. (iv) According to the NGSS guidelines, teachers can select the SEPs to be used and consider how these practices ladder up the students' conceptual understanding. (v) Next, teachers select the most appropriate CCCs. Then, (vi) teachers think about ways to incorporate the three dimensions of NGSS into each step of the 5E instructional model. Finally, (vii) teachers look at the Common Core Standards to identify areas of potential overlap, an essential ingredient for formulating an interdisciplinary approach across disparate subjects and for giving students deeper and more meaningful learning.

Overall, one lesson plan demonstrated the teachers' ability to plan three-dimensional, inquirybased lessons and another lesson plan revealed that the teachers had difficulty when trying to interweave the three dimensions of NGSS to effectively convey the understanding and explanation of a phenomenon. Throughout the PD and lesson development exercises, teachers were observed to be struggling in recognizing the possible components of eight NGSS-specified practices for consideration. As evidenced in subsections 4.2 and 4.4, more opportunities for teachers to fully conceptualize the NGSS vision are needed. In the spirit of research and standards describing the benefits of using technology devices, particularly robotics tool, in classrooms [25,26], this study demonstrated that teachers have the capacity to effectively integrate robotics-based activities and pedagogical strategies into their lesson plans. We encouraged the teachers to think of how technology-driven instructional activities can affect their teaching and to predict the degree of technology integration based on the SAMR model (Figure 1) in classrooms. The SAMR model helps us distinguish whether the activities enhance or transform students' learning experience as 
they seek to comprehend the lesson content. By reviewing and reflecting on the teacher-facilitator discussions during the lesson and activity planning, we argue that both the robotics activities examined in this study rise to the level of redefinition. Specifically, without the presence of robotics devices, generating and examining the percentage of bacteria growth over time or creating and examining chromosomes with mutation would not be possible within the confines of traditional single or even double period classes. As an example, for the antibiotics lesson, if we consider a traditional method of hands-on lesson, we would need diverse lab equipment including agar, Petri dishes, cotton swab, etc., and would need to wait for three days to observe the bacteria growth, which would necessitate a significant time and effort from teachers and students. With the robot-based simulator, all students in a classroom can engage in hands-on practice, multiple times, which transforms their learning experiences in one day.

Our PD facilitators and teachers further discussed the benefits of the use of robots for engineering education. Robotics offers students opportunities to interact with engineering artifacts through the designing, building, and programming of robots. Engaging students in the EDP with robotic-based lessons tasks them with formulating and implementing solutions under design constraints. Naturally, such a learning process constitutes a novel challenge to students but it affords them with opportunities, guided by teachers, to discover how to deal with their misconceptions and reconcile them with new knowledge to render a feasible design solution. To successfully explore and develop robotics design solutions, students develop an understanding of the technological principles, design strategies, and computational thinking, which endows them with engineering and computing literacy and practices. Finally, due to the natural tendency of robots to capture student attention, exposing students to robotics-based STEM learning activities can cultivate their interest and curiosity regarding engineering and technology. This has the potential to inspire them to pursue academic and career opportunities related to engineering.

Thinking systematically about all aspects that the standards recommend is not the norm for teachers because many of them already have their own ideas and materials for instruction. In fact, teachers in this study often exhibited and expressed the cognitive burden they experienced when attempting to apply systematic thinking to design lessons of their own. Although many teachers report having implemented the NGSS, recent research [27] has revealed this to be limited to the incorporation of a single dimension of NGSS into the curriculum rather than the full integration of its three dimensions in the context of a phenomenon. Moreover, teachers may be unfamiliar with a new technology tool and mechanisms to incorporate it for rendering new ways of learning different from their own prior experiences. Although numerous studies have been conducted in the area of teachers' lesson planning practices [4, 28-30], only a handful of studies have considered all three aspects to design lesson plans: technology for activities, 5E instructional model, and the NGSS. This study thus makes a unique contribution to demonstrating that the newly developed lesson plans concretely reflected these three elements and additionally exploring the quality of the lessons' three-dimensional and inquiry-based learning. However, there are numerous ways in 
which the PD programs can be further expanded and enhanced. After the teachers have developed their artifacts, the use of reflective inquiry would be one practical way to identify its positive or challenging aspects. Prior studies on PD programs have indicated that sustained support by researchers and facilitators helps teachers evolve their pedagogy-focused knowledge and skills and build-up their expertise to enact the technology integrated teaching practices [31-32]. PD activities should be intentionally grounded in assisting teachers to think about the robotic activities that provide exciting and relevant learning platforms and positively influence students' STEM academic performance.

\section{Acknowledgments}

This work is supported in part by the National Science Foundation grants DRK-12 DRL: 1417769, ITEST DRL: 1614085, and RET Site EEC: 1542286; and NY Space Grant Consortium grant 76156-10488. The authors thank the middle-school teachers for their participation in this study.

\section{References}

[1] R. Jalongo, S.A. Rieg, and V.R. Helterbran, Planning for Learning: Collaborative Approaches to Lesson Design and Review. New York, NY: Teachers College Press, 2007.

[2] P.D. John, "Lesson planning and the student teacher: Re-thinking the dominant model," Journal of Curriculum Studies, vol. 38. no. 4, pp. 483-498, 2006.

[3] NGSS Lead States, Next Generation Science Standards: For states, by states. Washington, DC: National Academies Press, 2013. www.nextgenscience.org.

[4] H. Jin and J.N. Mikeska, "Teaching NGSS-aligned lessons in science classrooms." Science Scope, vol. 41, no. 3, pp. 59-66, 2017.

[5] N. Tuttle, et al., "Investigating the impact of NGSS-aligned professional development on PreK-3 teachers' science content knowledge and pedagogy," Journal of Science Teacher Education, vol. 27, no. 7, pp. 717-745, 2016.

[6] R. Bybee, et al., The BSCE 5E Instructional Model: Origins and Effectiveness. 2006. Retrieved from http://bscs.org/sites/default/files/_legacy/BSCS 5E_Instructional_Model-Full_Report.pdf.

[7] K.D. Tanner, "Order matters: Using the 5E model to align teaching with how people learn." CBE—Life Sciences Education, vol. 9, no. 3, pp. 159-164, 2010.

[8] R.K. Enugu, Challenges Pre-service Science Teachers Face when Implementing a 5E Inquiry Model of Instruction. Doctoral dissertation, Fort Worth, TX: Texas Christian University, 2016.

[9] J. Settlage, "Understanding the learning cycle: Influences on abilities to embrace the approach by preservice elementary school teachers," Science Education, vol. 84, no. 1, pp. 43-50, 2000.

[10] E.A. Davis, D. Petish, and J. Smithey, "Challenges new science teachers face," Review of Educational Research, vol. 76, no. 4, pp. 607-651, 2006.

[11] B.J. Reiser, "What professional development strategies are needed for successful implementation of the Next Generation Science Standards?" ETS Invitational Symposium on Science Assessment, 2013. http://www.k12center.org/rsc/pdf/reiser.pdf. 
[12] R.R. Puentedura, "Transformation, technology, and education," 2006. Retrieved from http://hippasus.com/resources/tte/.

[13] J. Krajcik, et al., "Planning instruction to meet the intent of the Next Generation Science Standards," Journal of Science Teacher Education, vol. 25, no. 2, pp. 157-175, 2014.

[14] J. Hughes, "The role of teacher knowledge and learning experiences in forming technology-integrated pedagogy," Journal of Technology and Teacher Education, vol. 13, no. 2, pp. 277-302, 2005.

[15] R.R. Puentedura, "SAMR and TPCK: A hands-on approach to Classroom Practice," December 11, 2014. Retrieved from http://www.hippasus.com/rrpweblog/archives/000140.html.

[16] R. Karplus and H.D. Thier, A New Look at Elementary School Science. Chicago, IL: Rand McNally, 1967.

[17] M.J. Goldston, J. Dantzler, J. Day, and B. Webb, "A psychometric approach to the development of a 5E lesson plan scoring instrument for inquiry-based teaching," Journal of Science Teacher Education, vol. 24, no. 3, pp. 527-551, 2013.

[18] National Research Council, A Framework for K-12 Science Education: Practices, Crosscutting Concepts, and Core Ideas. Washington, DC: National Academies Press, 2012.

[19] R.W. Bybee, Translating the NGSS for Classroom Instruction. Arlington, VA: National Science Teachers Association, 2013.

[20] National Science Teachers Association, Designing Units and Lessons, 2014. Retrieved from https://ngss.nsta.org/designing-units-and-lessons.aspx.

[21] Massachusetts Department of Education, Massachusetts Science and Technology/Engineering Curriculum Framework. Malden, MA, 2006.

[22] Museum of Science, "Engineering is Elementary." [Online]. Available: https://www.eie.org/eiecurriculum/engineering-design-process.

[23] Achieve and National Science Teachers Association, EQuIP Rubric for Lessons and Units: Science. 2014. Retrieved from https://www.nextgenscience.org/sites/default/files/EQuIPRubricforSciencev3.pdf.

[24] S.L. Pruitt, "The next generation science standards: The features and challenges," Journal of Science Teacher Education, vol. 25, no. 2, pp. 145-156, 2014.

[25] I. Marulcu and M. Barnett, "Fifth graders' learning about simple machines through engineering design-based instruction using LEGO ${ }^{\mathrm{TM}}$ materials," Research in Science Education, vol. 43, no. 5, pp. 1825-1850, 2013.

[26] M. Parappilly, C. Hassam, and R.J. Woodman, "Race to improve student understanding of uncertainty: Using LEGO race cars in the physics lab," American Journal of Physics, vol. 86, no. 1, pp. 68-76, 2018.

[27] K.L. Huff, "Addressing three common myths about the Next Generation Science Standards," The Science Teacher, vol. 83, no., pp. 55-58, 2016.

[28] C.M. Sias, L.S. Nadelson, S.M. Juth, and A.L. Seifert, "The best laid plans: Educational innovation in elementary teacher generated integrated STEM lesson plans," The Journal of Educational Research, vol. 110, no. 3, pp. 227-238, 2017.

[29] D.E. Strangis, R.M. Pringle, and H.T. Knopf, "Road map or roadblock? Science lesson planning and preservice teachers," Action in Teacher Education, vol. 28, no. 1, pp. 73-84, 2006.

[30] E.D. Wischow, Development and Analysis of Lesson Plans for Nanoscience, Engineering, and Technology. Doctoral dissertation, West Lafayette, IN: Purdue University, 2008.

[31] M. Duran et al., "Impact of research-based professional development: Investigation of inservice teacher learning and practice in Wiki integration," Journal of Research on Technology in Education, vol. 44, no. 4, pp. $313,2012$.

[32] Y. Liao, Coaching in teacher professional development for technology integration: Examining teacher practices and perceptions. Doctoral dissertation, Bloomington, IN: Indiana University, 2018. 


\section{Appendix A: EQuIP Rubric Ver 3. Category I: Alignment to the NGSS}

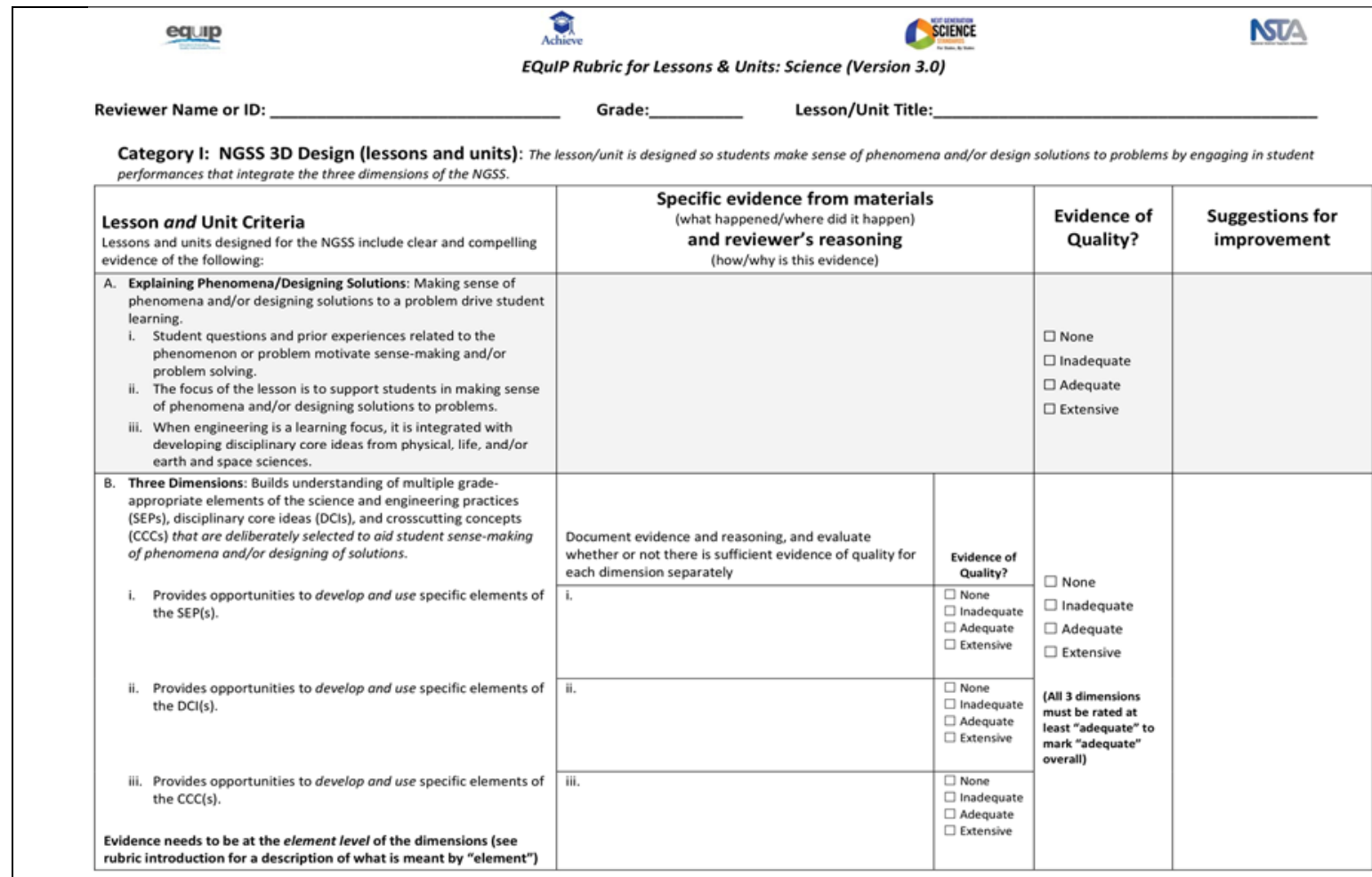

EQuip Rubric for Lessons \& Units: Science (Version 3.0

\begin{tabular}{|c|c|c|c|}
\hline $\begin{array}{l}\text { C. Integrating the Three Dimensions: Student sense-making of } \\
\text { phenomena and/or designing of solutions requires student } \\
\text { performances that integrate elements of the SEPS, CCCS, and DCIs. }\end{array}$ & & $\begin{array}{l}\square \text { None } \\
\square \text { Inadequate } \\
\square \text { Adequate } \\
\square \text { Extensive }\end{array}$ & \\
\hline $\begin{array}{l}\text { Rating for Category L. NGSS 3D Design-lessons } \\
\text { After carefully weighing the evidence, reasoning, and suggestions for } \\
\text { improvement, rate the degree to which there is enough evidence to } \\
\text { support a claim that the lesson meets these criteria. } \\
\text { If you are evaluating an instructional unit rather than a single lesson, } \\
\text { continue on to evaluate criteria D-f and rate Category I overall } \\
\text { below. }\end{array}$ & $\begin{array}{l}\text { Lesson Rating scale for Category I (Criteria A-C only): } \\
\text { 3: Extensive evidence to meet at least two criteria } \\
\text { (and at least adequate evidence for the third) } \\
\text { 2: Adequate evidence to meet all three criteria in the category } \\
\text { 1: Adequate evidence to meet at least one criterion in the category, } \\
\text { but insufficient evidence for at least one other criterion } \\
\text { 0: Inadequate (or no) evidence to meet any of the criteria in the category }\end{array}$ & & 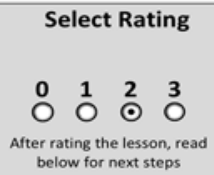 \\
\hline
\end{tabular}

What's next if the lesson rating is less than a 2?

If the rubric is being used to approve or vet resources and the lesson or unit does not score at least a "2" in Category I: NGSS 3D Designed, the review should stop and feedback should be provided to the lesson developer(s) to guide revisions. If the rubric is being used locally for revising and building lessons, professional judgment should guide whether to continue reviewing the lesson. Categories II and III may be time consuming to evaluate if Category I has not been met and the feedback may not be useful if significant revisions are needed in Category I, but evaluating these criteria in a group may support deeper and more common understanding of the criteria in these categories and more complete feedback to the lesson developer (if they are not in the room) so that Categories II and III are more likely to be met with fewer cycles of revision.

What's next if the lesson rating is a 2 or 3 ?

If you are evaluating a lesson that shows sufficient evidence of quality to warrant a rating of either a 2 or a 3 for Category l, proceed to Category II: NGSS Instructional Supports 


\section{Appendix B: 5E Inquiry Lesson Plan Version 2 Rubric (5E ILPv2)}

\begin{tabular}{|c|c|}
\hline Exploration-Phase 1 (Engage and Explore) & \\
\hline $\begin{array}{l}\text { Engage item } 1 \\
\text { The engage elicits students' prior knowledge (based upon the objectives) }\end{array}$ & $\begin{array}{lllll}0 & 1 & 2 & 3 & 4\end{array}$ \\
\hline $\begin{array}{l}\text { Engage item } 2 \\
\text { The engage raises student interest/motivation to learn }\end{array}$ & $\begin{array}{llll}1 & 2 & 3 & 4\end{array}$ \\
\hline $\begin{array}{l}\text { Engage item } 3 \\
\text { The engage provides opportunities for student discussion/questions (or invites student questions) }\end{array}$ & $\begin{array}{lllll}\mathbf{0} & 1 & 2 & 3 & 4\end{array}$ \\
\hline $\begin{array}{l}\text { Engage item } 4 \\
\text { The engage leads into the exploration }\end{array}$ & $\begin{array}{lllll}0 & 1 & 2 & 3 & 4\end{array}$ \\
\hline $\begin{array}{l}\text { Explore item } 1 \\
\text { During the explore phase, teachers present instructions }\end{array}$ & $\begin{array}{lllll}0 & 1 & 2 & 3 & 4\end{array}$ \\
\hline $\begin{array}{l}\text { Explore item } 2 \\
\text { Learning activities in the exploration phase involves hands-on/minds-on activities }\end{array}$ & $\begin{array}{lllll}0 & 1 & 2 & 3 & 4\end{array}$ \\
\hline $\begin{array}{l}\text { Explore item } 3 \\
\text { Learning activities in the exploration phase are student-centered (When appropriate, teacher } \\
\text { questions evoke the learners' ideas and/or generate new questions from students. Student inquiry } \\
\text { may involve student questioning, manipulating objects, developing inquiry skills (as appropriate) } \\
\text { and developing abstract ideas). }\end{array}$ & $\begin{array}{lllll}0 & 1 & 2 & 3 & 4\end{array}$ \\
\hline $\begin{array}{l}\text { Explore item } 4 \\
\text { The inquiry activities of the explore show evidence of student learning (formative/authentic } \\
\text { assessment). }\end{array}$ & $\begin{array}{lllll}0 & 1 & 2 & 3 & 4\end{array}$ \\
\hline Invention-Phase 2 (Explain) & \\
\hline $\begin{array}{l}\text { Explain item } 1 \\
\text { There is a logical transition from the explore phase to the explain phase }\end{array}$ & $\begin{array}{lllll}0 & 1 & 2 & 3 & 4\end{array}$ \\
\hline $\begin{array}{l}\text { Explain item } 2 \\
\text { The explain includes teacher questions that lead to the development of concepts and skills (Draws } \\
\text { upon the explore activities/or data collected during the explore activities) }\end{array}$ & $\begin{array}{lllll}0 & 1 & 2 & 3 & 4\end{array}$ \\
\hline $\begin{array}{l}\text { Explain item } 3 \\
\text { The explain includes mixed divergent and convergent questions for interactive discussion } \\
\text { facilitated by teacher and/or students to develop concepts or skills }\end{array}$ & $\begin{array}{lllll}0 & 1 & 2 & 3 & 4\end{array}$ \\
\hline $\begin{array}{l}\text { Explain item } 4 \\
\text { The explain includes a complete explanation of the concept (s) and/or skill(s) taught }\end{array}$ & $\begin{array}{lllll}0 & 1 & 2 & 3 & 4\end{array}$ \\
\hline $\begin{array}{l}\text { Explain item } 5 \\
\text { The explain phase provides a variety of approaches to explain and illustrate the concept or skill. } \\
\text { (For example, approaches might include but are not limited to the use of technology, virtual field } \\
\text { trips, demonstrations, cooperative group discussions, panel discussions, interview of guest } \\
\text { speaker, video/print/audio/ computer program materials, or teacher explanations.) }\end{array}$ & $\begin{array}{lllll}0 & 1 & 2 & 3 & 4\end{array}$ \\
\hline $\begin{array}{l}\text { Explain item } 6 \\
\text { The discussions or activity during the explain phase allows the teacher to assess students' present } \\
\text { understanding of concept(s) or skill(s) }\end{array}$ & $\begin{array}{lllll}0 & 1 & 2 & 3 & 4\end{array}$ \\
\hline Expansion-Phase 3 (Elaborate and Evaluate) & \\
\hline $\begin{array}{l}\text { Elaborate item } 1 \\
\text { There is a logical transition from the explain phase to the elaborate phase }\end{array}$ & $\begin{array}{lllll}0 & 1 & 2 & 3 & 4\end{array}$ \\
\hline $\begin{array}{l}\text { Elaborate item } 2 \\
\text { The elaborate activities provide students with the opportunity to apply the newly acquired } \\
\text { concepts and skills into new areas }\end{array}$ & $\begin{array}{lllll}0 & 1 & 2 & 3 & 4\end{array}$ \\
\hline $\begin{array}{l}\text { Elaborate item } 3 \\
\text { The elaborate activities encourage students to find real-life (every day) connections with the } \\
\text { newly acquired concepts or skills }\end{array}$ & $\begin{array}{lllll}\mathbf{0} & 1 & 2 & 3 & 4\end{array}$ \\
\hline $\begin{array}{l}\text { Evaluation item } 1 \\
\text { The lesson includes summative evaluation, which can include a variety of forms/approaches. }\end{array}$ & $\begin{array}{lllll} & 1 & 2 & 3 & 4\end{array}$ \\
\hline $\begin{array}{l}\text { Evaluation item } 2 \\
\text { The evaluation matches the objectives }\end{array}$ & $\begin{array}{lllll} & 1 & 2 & 3 & 4\end{array}$ \\
\hline $\begin{array}{l}\text { Evaluation item } 3 \\
\text { The evaluation criteria are clear and appropriate }\end{array}$ & $\begin{array}{lllll}0 & 1 & 2 & 3 & 4\end{array}$ \\
\hline $\begin{array}{l}\text { Evaluation item } 4 \\
\text { The evaluation criteria are measurable (i.e., rubrics) }\end{array}$ & $\begin{array}{lllll}0 & 1 & 2 & 3 & 4\end{array}$ \\
\hline
\end{tabular}

